\title{
Effect of the El Niño Decaying Pace on the East Asian Summer Monsoon Circulation Pattern during Post-El Niño Summers
}

\author{
Wenping Jiang ${ }^{1}$, Gen $\mathrm{Li}^{1,2, * \mathbb{D}}$ and Gongjie Wang ${ }^{3}$ \\ 1 Key Laboratory of Marine Hazards Forecasting, Ministry of Natural Resources, College of Oceanography, \\ Key Laboratory of Ministry of Education for Coastal Disaster and Protection, Hohai University, \\ Nanjing 210024, China; jiangwenping@hhu.edu.cn \\ 2 Southern Marine Science and Engineering Guangdong Laboratory (Zhuhai), Zhuhai 510000, China \\ 3 People's Liberation Army 66199 Troops, Beijing 100043, China; wanggj_9015@sina.com \\ * Correspondence: ligen@hhu.edu.cn
}

check for

updates

Citation: Jiang, W.; Li, G.; Wang, G. Effect of the El Niño Decaying Pace on the East Asian Summer Monsoon Circulation Pattern during Post-El

Niño Summers. Atmosphere 2021, 12, 140. https://doi.org/10.3390/ atmos12020140

Received: 29 December 2020

Accepted: 18 January 2021

Published: 22 January 2021

Publisher's Note: MDPI stays neutra with regard to jurisdictional claims in published maps and institutional affiliations.

Copyright: (c) 2021 by the authors. Licensee MDPI, Basel, Switzerland. This article is an open access article distributed under the terms and conditions of the Creative Commons Attribution (CC BY) license (https:// creativecommons.org/licenses/by/ $4.0 /)$.

\begin{abstract}
El Niño events vary from case to case with different decaying paces. In this study, we demonstrate that the different El Niño decaying paces have distinct impacts on the East Asian monsoon circulation pattern during post-El Niño summers. For fast decaying (FD) El Niño summers, a large-scale anomalous anticyclone dominates over East Asia and the North Pacific from subtropical to mid-latitude; whereas, the East Asian monsoon circulation display a dipole pattern with anomalous northern cyclone and southern anticyclone for slow decaying (SD) El Niño summers. The difference in anomalous East Asian monsoon circulation patterns was closely associated with the sea surface temperature (SST) anomaly patterns in the tropics. In FD El Niño summers, the cold SST anomalies in the tropical central-eastern Pacific and warm SST anomalies in the Maritime Continent induce the anticyclone anomalies over the Northwest Pacific. In contrast, the warm Kelvin wave anchored over the tropical Indian Ocean during SD El Niño summers plays a crucial role in sustaining the anticyclone anomalies over the Northwest Pacific. In particular, the opposite atmospheric circulation anomaly patterns over Northeast Asia and the mid-latitude North Pacific are mainly modulated by the stationary Rossby wave trains triggered by the opposite SST anomalies in the tropical eastern Pacific during FD and SD El Niño summers. Finally, the effect of distinct summer monsoon circulation patterns associated with the El Niño decay pace on the summer climate over East Asia are also discussed.
\end{abstract}

Keywords: El Niño; decaying pace; East Asian monsoon circulation; post-El Niño summers

\section{Introduction}

The East Asian summer monsoon (EASM) is the most important climate system over East Asia and has strong interannual variability. The anomalous EASM often causes serious disasters, such as floods, droughts, and related heat waves over East Asia, leading to huge economic losses and casualties [1-3]. Therefore, many efforts have been devoted to understanding the interannual variability of the EASM. The El Niño-Southern Oscillation (ENSO) is regarded as one of the most important factors controlling the interannual variability of the EASM [4-9]. An anomalous anticyclone over the Northwest Pacific (NWPAC)—developing in the El Niño mature winter and persisting into the following spring and summer-plays an important role in linking El Niño and East Asia climate [10-13]. The NWPAC dominates over the Northwest Pacific (NWP) and transports moisture to Eastern China and Japan, leading to cold and wet anomalies in the Yangtze River valley and Japan and warm and dry anomalies in the local NWP.

Most previous studies have selected all El Niño events in the preceding winter to investigate their effects on East Asian summer climate in the El Niño decaying year. However, El Niño events vary from case to case, with complex temporal and spatial diversities. The El Niño events can be classified into two types based on the periodicity 
of ENSO cycle $[14,15]$. One is the quasi-biennial El Niño with a 2-3 year cycle, which transforms phase in the following summer and is referred to as a fast decaying (FD) El Niño. The other is the low-frequency El Niño with a typical period of 4-5 years, which persists its single phase to the following summer and autumn and is referred to as a slow decaying (SD) El Niño.

The difference in El Niño decaying paces leads to distinct impacts on the NWPAC anomalies and East Asia summer climate [16-18]. An FD El Niño leads to stronger NWPAC anomalies in the following summer than an SD El Niño [16,18]. Correspondingly, more pronounced positive precipitation anomalies generate over the Yangzi River basin during FD El Niño summers than those during SD El Niño summers [18]. What's more, the NWP subtropical high (NWPSH) experiences a slight northward shift during SD El Niño summers, and the corresponding tripolar rainfall anomalies have weak sub-seasonal variations. While the NWPSH clearly experiences two northward shifts when El Niño decays faster [17].

The mechanisms of maintaining the NWPAC anomalies in two distinct El Niño decaying summers have been investigated in Jiang et al. [18]. During FD El Niño summers, the cold SST anomalies in the tropical central-eastern Pacific (TCEP) play a leading role in maintaining the NWPAC anomalies through triggering a Rossby wave response, and the warm SST anomalies around the Maritime Continent (MC) also facilitate the development of the NWPAC anomalies by forcing a Kelvin wave response and enhancing the Hadley circulation anomalies. Meanwhile, during the SD El Niño summers, the Kelvin wave in response to warm tropical Indian Ocean (TIO) SST anomalies plays a crucial role in maintaining the NWPAC anomalies, whereas the Rossby wave in response to warm TCEP SST anomalies weakens the western part of the NWPAC anomalies.

In contrast to numerous studies focusing on the effects of the ENSO on the NWP circulation and climate in East Asia [8,17-20], less attention has been paid to the impacts on the mid-latitude circulation and the climate anomalies in East Asia. However, some studies suggested that the variability of the North Pacific high (NPH) plays an important role in modulating the Northern Hemisphere planetary waves and summer monsoon systems [21,22]. Moreover, previous studies suggested that the ENSO-related tropical SST anomalies could modulate the variability of NPH through exciting a Rossby wavetrain [23,24]. Nevertheless, the impacts of El Niño decaying pace on the mid-latitude atmospheric circulation and climate in East Asia during El Niño decaying summers are still unknown, and their mechanisms also deserve to be explored. In this study, we tried to figure out which region of the tropical SST anomalies should play a leading role in the NPH variability in two types of El Niño decaying summers through a suite of numerical experiments by using an atmospheric general circulation model (AGCM).

The structure of this paper is organized as follows. Section 2 provides a brief description of datasets and methods. In Section 3, we contrast the characteristics of atmospheric circulation over East Asia and the North Pacific in different El Niño decaying summers. We analyzed the mechanisms of different effects on extratropical atmospheric variability in Section 4. Section 5 delineates the different climate responses over East Asia during different El Niño decaying summers. Finally, some conclusions are presented in Section 6.

\section{Data Mining and Methodology}

The monthly mean atmospheric variables, including wind, geopotential height, are from the National Centers for Environment Prediction-National Center for Atmospheric Research (NCEP/NCAR) reanalysis dataset with a horizontal resolution of $2.5^{\circ} \times 2.5^{\circ}$, covering the period from January 1948 to the present [25]. The SST used in this study was from the monthly mean Extended Reconstruction of Historical Sea Surface Temperature version 5 (ERSST5) dataset [26], which has a horizontal resolution of $2^{\circ} \times 2^{\circ}$. Monthly rainfall and air temperature datasets for the period 1950-2017 are provided by the Climatic Research Unit (CRU) at the University of East Anglia. 
We denote the El Niño developing year as year(0) and its decay year as year(1). Thus, the ENSO mature winter (December-January-February, DJF) is symbolized as D(0)JF(1), the following spring (March-April-May, MAM) is denoted as MAM(1), and the following summer (June-July-August, JJA) is denoted as JJA(1). We focus on the ENSO decay summer season (JJA(1)) from 1950 to 2017. All data were interpolated onto the same $2.5^{\circ} \times 2.5^{\circ}$ grid, and their long-term trends and annual cycle were removed before analysis. The climatological annual cycle was defined as the 1950-2017 mean, and anomalies were calculated by subtracting the monthly mean values from their respective climatology.

In order to eliminate the influence of the ENSO asymmetry, we only selected El Niño cases. The El Niño cases were selected when the standardized $\mathrm{D}(0) \mathrm{JF}(1)$ Niño-3.4 index, defined as the SST anomalies averaged over the region of $5^{\circ} \mathrm{S}-5^{\circ} \mathrm{N}$ and $120^{\circ}-170^{\circ} \mathrm{W}$ were larger than 0.5. All El Niño events were divided into two groups according to their different cycle lengths. The cases with negative JJA(1) Niño-4 index (the averaged SST anomalies of $5^{\circ} \mathrm{S}-5^{\circ} \mathrm{N}$ and $160^{\circ} \mathrm{E}-150^{\circ} \mathrm{W}$ ) were classified as FD El Niños, whereas the others as SD El Niños. The criterion for selecting cases follows the method of Jiang et al. [18]. The classification of all El Niño cases is shown in Table 1. A composite analysis was used in this study, and the statistical significance for the composite analysis is estimated with a two-tailed Student's $t$-test.

Table 1. The selected fast decaying (FD) El Niño years and slow decaying (SD) El Niño years for the period of 1950-2017.

\begin{tabular}{cc}
\hline Types & Years \\
\hline \multirow{2}{*}{ FD El Niños } & 1951-1952, 1953-1954, 1963-1964, 1969-1970, 1972-1973, 1977-1978, 1987-1988, \\
& $1997-1998,2006-2007,2009-2010$ \\
\hline \multirow{2}{*}{ SD El Niños } & $1957-1958,1958-1959,1965-1966,1968-1969,1976-1977,1979-1980,1982-1983$, \\
& $1986-1987,1991-1992,1994-1995,2002-2003,2004-2005,2015-2016$ \\
\hline
\end{tabular}

To help understand the effect of SST anomalies in different regions on the circulation anomalies over the North Pacific, we performed a suite of sensitivity experiments by using ECHAM5, which is an AGCM from the Max Planck Institute for Meteorology [27]. The model runs at a horizontal resolution of spectral triangular 63 (T63), which is roughly equivalent to $1.875^{\circ}$ (latitude) $\times 1.875^{\circ}$ (longitude), with 31 vertical levels in a hybrid sigma-pressure coordinate system. The mass flux scheme [28] is applied to represent the deep, shallow, and middle convection. The moisture convergence closure was replaced by a convective available potential energy-based closure scheme [29]. A standard control run is one in which the SST boundary conditions were forced by the climatological SST and sea ice with the seasonal cycle. Six sets of sensitivity experiments were conducted with the modified SST boundary conditions in some specified domain (i.e., TCEP, TIO, $\mathrm{MC}$ ). The details of SST boundary conditions in seven experiments (i.e., Control, FD_All, SD_All, FD_TCEP,SD_TCEP, FD_MC,SD_TIO) are summarized in Table 2. The differences between the sensitivity runs and the control runs (hereafter denoted as FD_All-Control, SD_All-Control, FD_MC-Control, FD_TCEP-Control, SD_TIO-Control, and SD_TCEP_ Control) present the individual role of specific SST anomalies to the circulation anomalies. Each set of experiment is integrated for 50 years, and the results of the last 30 years are averaged to reduce the influence of internal variability. Further details of the experimental result are described in Section 4. 
Table 2. Descriptions of control and sensitivity experiments.

\begin{tabular}{|c|c|}
\hline $\begin{array}{l}\text { Experiment } \\
\text { Name }\end{array}$ & SST Boundary Condition \\
\hline Control & Climatological SST with seasonal cycle. \\
\hline FD_All & $\begin{array}{l}\text { The SST anomalies in the tropics }\left(20^{\circ} \mathrm{S}-20^{\circ} \mathrm{N}\right) \text { in the composite FD El Niño years } \\
\text { from January to December were added on climatological SST. }\end{array}$ \\
\hline SD_All & Similar to FD_All run, but SST anomalies from composite SD El Niño years. \\
\hline FD_TCEP & $\begin{array}{l}\text { The SST anomalies in the TCEP }\left(20^{\circ} \mathrm{S}-20^{\circ} \mathrm{N}, 170^{\circ} \mathrm{E}-80^{\circ} \mathrm{W}\right) \text { in the composite FD } \\
\text { El Niño years from January to December were added on climatological SST. }\end{array}$ \\
\hline SD_TCEP & Similar to FD_TCEP run, but SST anomalies from composite SD El Niño years. \\
\hline FD_MC & $\begin{array}{l}\text { The SST anomalies in the } \mathrm{MC}\left(20^{\circ} \mathrm{S}-20^{\circ} \mathrm{N}, 90^{\circ}-150^{\circ} \mathrm{E}\right) \text { in the composite FD El } \\
\text { Niño years from January to December were added on climatological SST. }\end{array}$ \\
\hline SD_TIO & $\begin{array}{l}\text { The SST anomalies in the } \mathrm{TIO}\left(20^{\circ} \mathrm{S}-20^{\circ} \mathrm{N}, 40^{\circ}-110^{\circ} \mathrm{E}\right) \text { in the composite SD El } \\
\text { Niño years from January to December were added on climatological SST. }\end{array}$ \\
\hline
\end{tabular}

\section{Relationship between Circulation Anomalies in the North Pacific and El Niño Decay Pace}

Figure 1 shows the evolution of the SST anomaly pattern from the El Niño mature winter to the following summer. The evolution of El Niño-related SST anomalies shows conspicuous diversity when the SST anomalies are composited individually based on two different El Niño decay paces. During FD El Niño years, warm SST anomalies in the TCEP and the TIO declined fast and transform phases during the following spring and summer, displaying a cold-warm-cold SST anomaly pattern from the TIO, the MC to the TCEP in the summer (Figure 1a-c). Conversely, warm SST anomalies in the TCEP and the TIO persisted to the decaying summer in SD El Niño years, displaying a warm-cold-warm SST anomaly pattern in the tropical Indian Ocean and Pacific (Figure 1d-f).

(a) FD El Niño

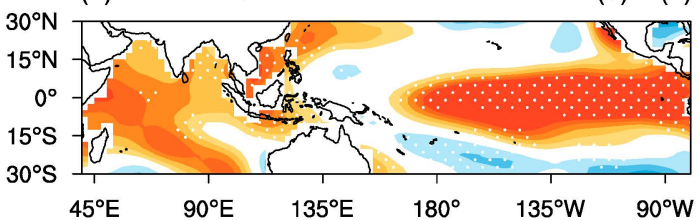

(b)

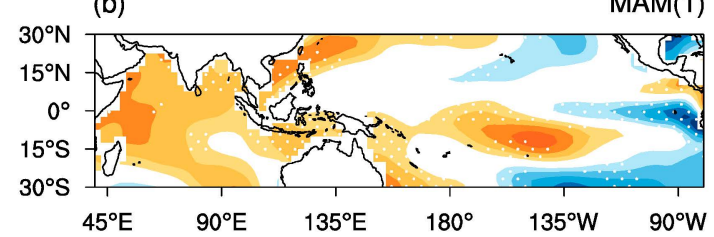

(c)

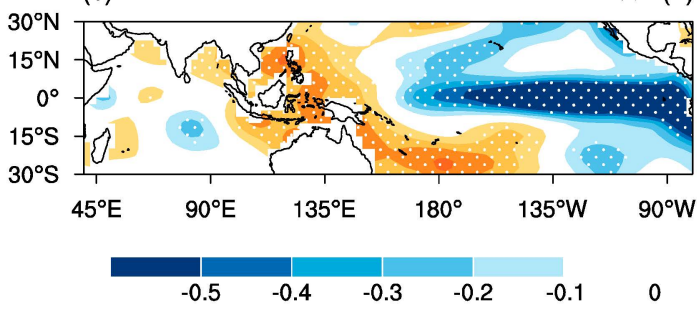

(d) SD El Niño

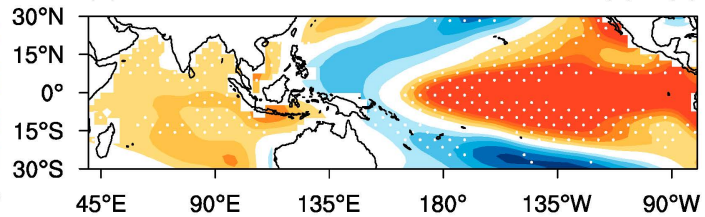

(e) $\operatorname{MAM(1)}$
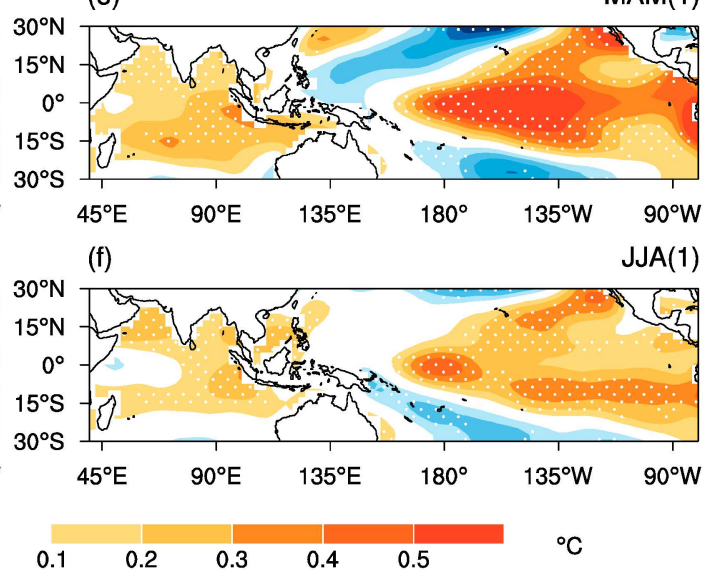

Figure 1. Composite SST anomalies of FD El Niños from (a) December-January-February (D(0)JF(1)) to (c) June-JulyAugust (JJA(1)). (d-f) As in (a-c), but for SD El Niños. White dots indicate where the significance exceeds the $90 \%$ confidence level. 
To investigate the circulation response in the North Pacific to the different ENSO decay summer, the composite of $850 \mathrm{hPa}$ wind anomalies and geopotential height anomalies during the two types of El Niño decaying summer are shown in Figure 2. Despite the distinct SST anomaly pattern during two El Niño decaying summers, there were still anticyclone anomalies during the following summer of both types of El Niño (Figure 2), located in the NWP region (around $10^{\circ}-30^{\circ} \mathrm{N}, 100^{\circ}-160^{\circ} \mathrm{E}$ ). It is noteworthy that the circulation anomalies over Northeast Asia and the mid-latitude North Pacific during the two El Niño decaying summers conspicuously differed from each other. During FD El Niño summers, the positive geopotential height anomalies could extend to Northeast Asia and the midlatitude North Pacific, and almost the whole North Pacific and East Asia were dominated by the anticyclone anomalies. While in SD El Niño summers, there was a significant dipole pattern of $850 \mathrm{hPa}$ geopotential height anomalies over the North Pacific with positive geopotential height anomalies over the NWP and negative geopotential height anomalies over the mid-latitude North Pacific and Northeast Asia, accompanied by an anomalous anticyclone and an anomalous cyclone, respectively.

(a) FD El Niño

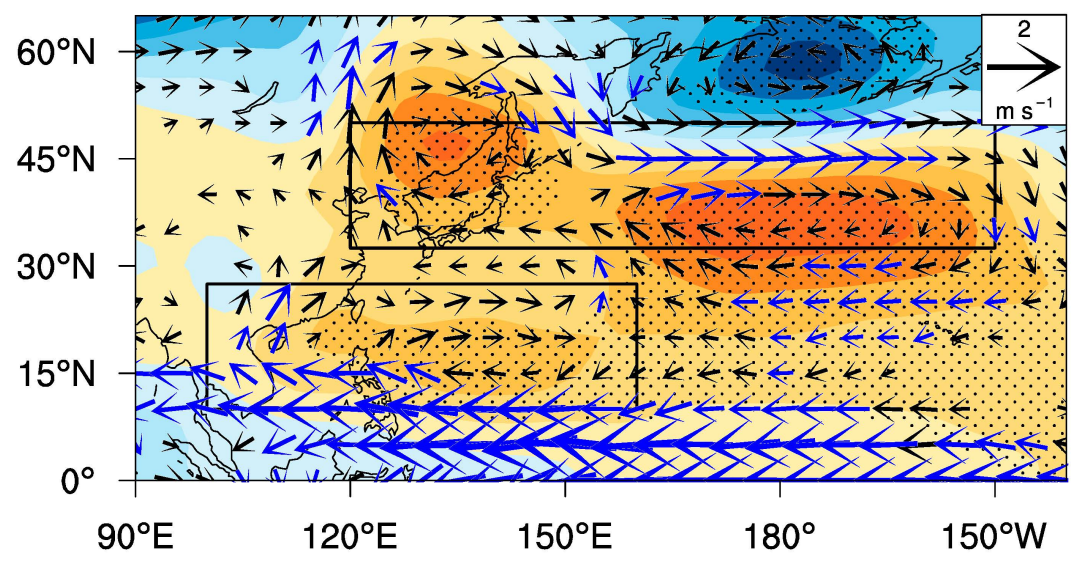

(b) SD EI Niño

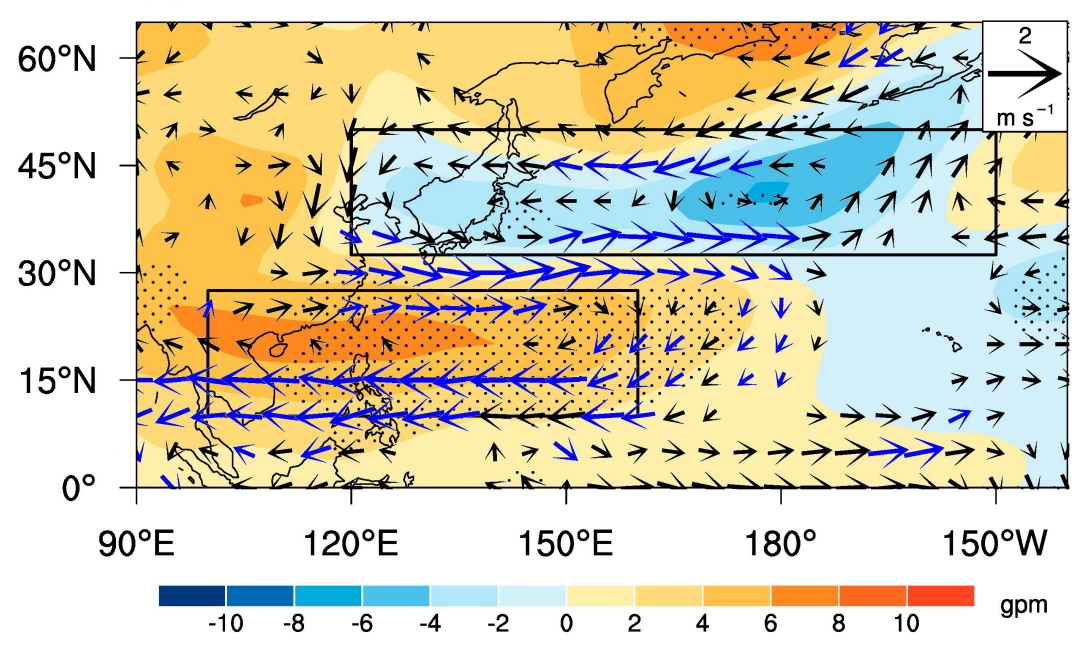

Figure 2. Composite $850 \mathrm{hPa}$ geopotential height anomalies (shading) and wind anomalies (vectors) in (a) FD El Niño summers and (b) SD El Niño summers. Black dots and blue arrows indicate where the significance exceeds the $90 \%$ confidence level.

Yun et al. [22] pointed out that the out-of-phase variability of the circulation over the North Pacific tended to be weakened after the late 1990s. Interestingly, the period of ENSO also experienced an interdecadal change in the late 1990s, from a low-frequency ENSO 
cycle to a quasi-biennial ENSO cycle [30,31]. Thus, we suspect that the phase relationships between the circulation anomalies over the NWP and the mid-latitude North Pacific may be related to the length of ENSO cycle. To verify this, we provide a longer wavelet analysis of ENSO from 1950 to 2017 in Figure 3a. The wavelet power spectrum showed that the length of ENSO cycle repeated twice from a low-frequency 4-6-year periodicity to a 2-3-year cycle from the 1950s to the 2010s. Specifically, ENSO variability was dominated by a weak 4-6-year cycle before the mid-1960s, changing into a 2-3-year cycle from the mid-1960s to the mid-1970s, and then ENSO variability has a strong 4-6-year periodicity from the early1980s to the early-1990s and a leading periodicity of 2-3-year afterward. Correspondingly, the phase relationship between the NWP and the mid-latitude North Pacific also repeated twice from an out-of-phase relationship to an in-phase relationship, which was confirmed by a 13-year running correlation analysis between the NWPSH and NPH indices shown in Figure $3 \mathrm{~b}$. All the above results indicate that an FD El Niño summer is often accompanied by an in-phase variability of circulation anomalies over the NWP and the mid-latitude North Pacific. Conversely, an SD El Niño summer tended to generate an out-of-phase variability of circulation anomalies over the NWP and the mid-latitude North Pacific.

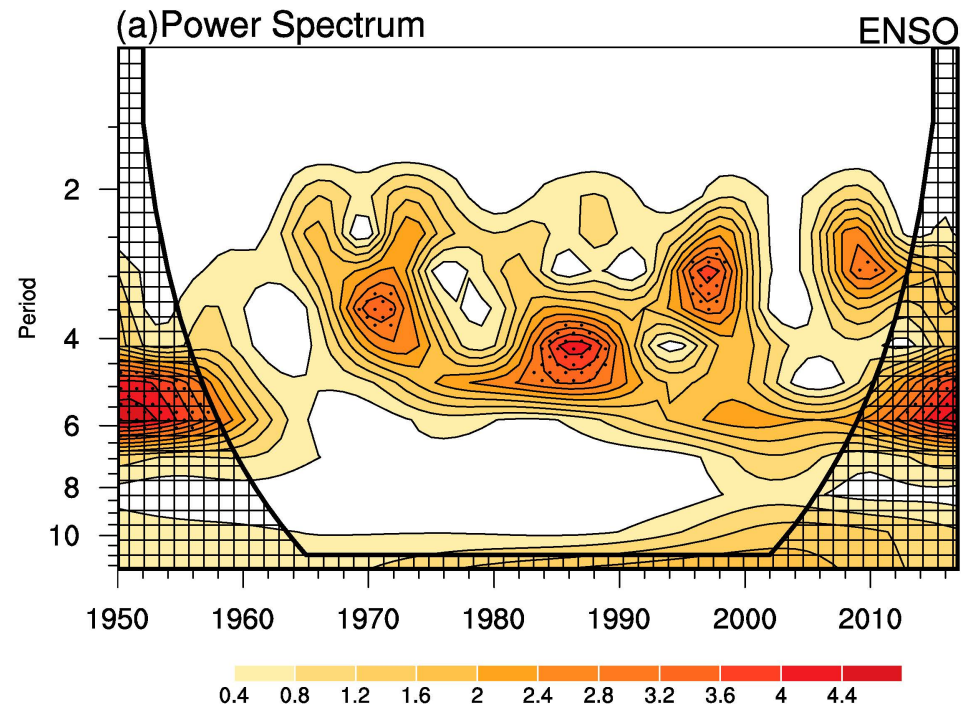

(b) Sliding Cor

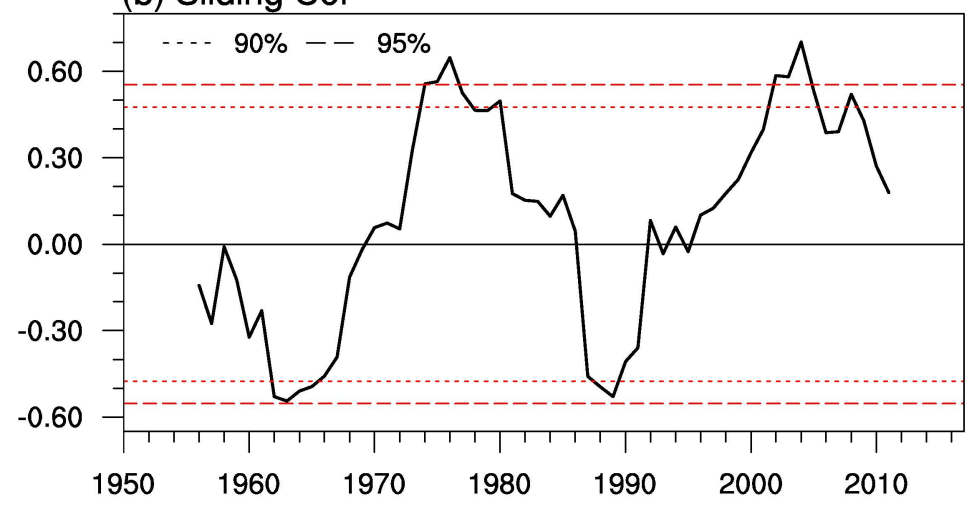

Figure 3. (a) Wavelet power spectrum of the Niño-3.4 index. The regions exceeding the $95 \%$ confidence level against red noise are dotted. (b) 13-year running correlation coefficients between the NWPSH index (defined as the JJA(1) averaged geopotential height anomalies over the region of $10^{\circ}-27.5^{\circ} \mathrm{N}$ and $100^{\circ}-160^{\circ} \mathrm{E}$ (black box highlights the region over the Northwest pacific NWP in Figure 3)) and the North Pacific high (NPH) index (defined as the JJA(1) averaged geopotential height anomalies over the region of $32.5^{\circ}-50^{\circ} \mathrm{N}$ and $120^{\circ} \mathrm{E}-150^{\circ} \mathrm{W}$ (black box highlights the region over the mid-latitude North Pacific in Figure 3)). 


\section{Numerical Experiment on Distinct Impacts of El Niño Decay Pace on Extratropical Circulation}

To identify the contribution of SST anomalies in different regions on the circulation anomalies over the North Pacific, we perform a suite of sensitivity experiments by using ECHAM5. The SST boundary conditions in FD_All run and SD_All run were the composited SST anomalies in FD El Niño year (Figure 4a) and SD El Niño year (Figure 4b) added to climatological SST in the whole tropics $\left(20^{\circ} \mathrm{S}-20^{\circ} \mathrm{N}\right)$, respectively. Since significant SST anomalies appeared in the MC $\left(20^{\circ} \mathrm{S}-20^{\circ} \mathrm{N}, 90^{\circ}-150^{\circ} \mathrm{E}\right)$ and TCEP $\left(20^{\circ} \mathrm{S}-20^{\circ} \mathrm{N}\right.$, $\left.170^{\circ} \mathrm{E}-80^{\circ} \mathrm{W}\right)$ during FD El Niño summers and the TIO $\left(20^{\circ} \mathrm{S}-20^{\circ} \mathrm{N}, 40^{\circ}-110^{\circ} \mathrm{E}\right)$ and TCEP $\left(20^{\circ} \mathrm{S}-20^{\circ} \mathrm{N}, 170^{\circ} \mathrm{E}-80^{\circ} \mathrm{W}\right)$ during SD El Niño summers (Figure 1). Thus, we designed another four sets of sensitivity experiments with the composited SST anomalies in these key oceans individually added to the climatological SST, referred to as the FD_MC run, FD_TCEP run, SD_TIO run, and SD_TCEP run, respectively. More details of the experiments are list in Table 2. The differences between the sensitivity runs and the control runs (hereafter denoted as FD_All-Control, SD_All-Control, FD_MC-Control, FD_TCEP-Control, SD_TIO-Control, and SD_TCEP-Control) present the individual role of specific SST anomalies to the circulation anomalies. To reduce uncertainties, each set of experiments was integrated for 50 years, and the results of the last 30 years were averaged to reduce the influence of internal variability.
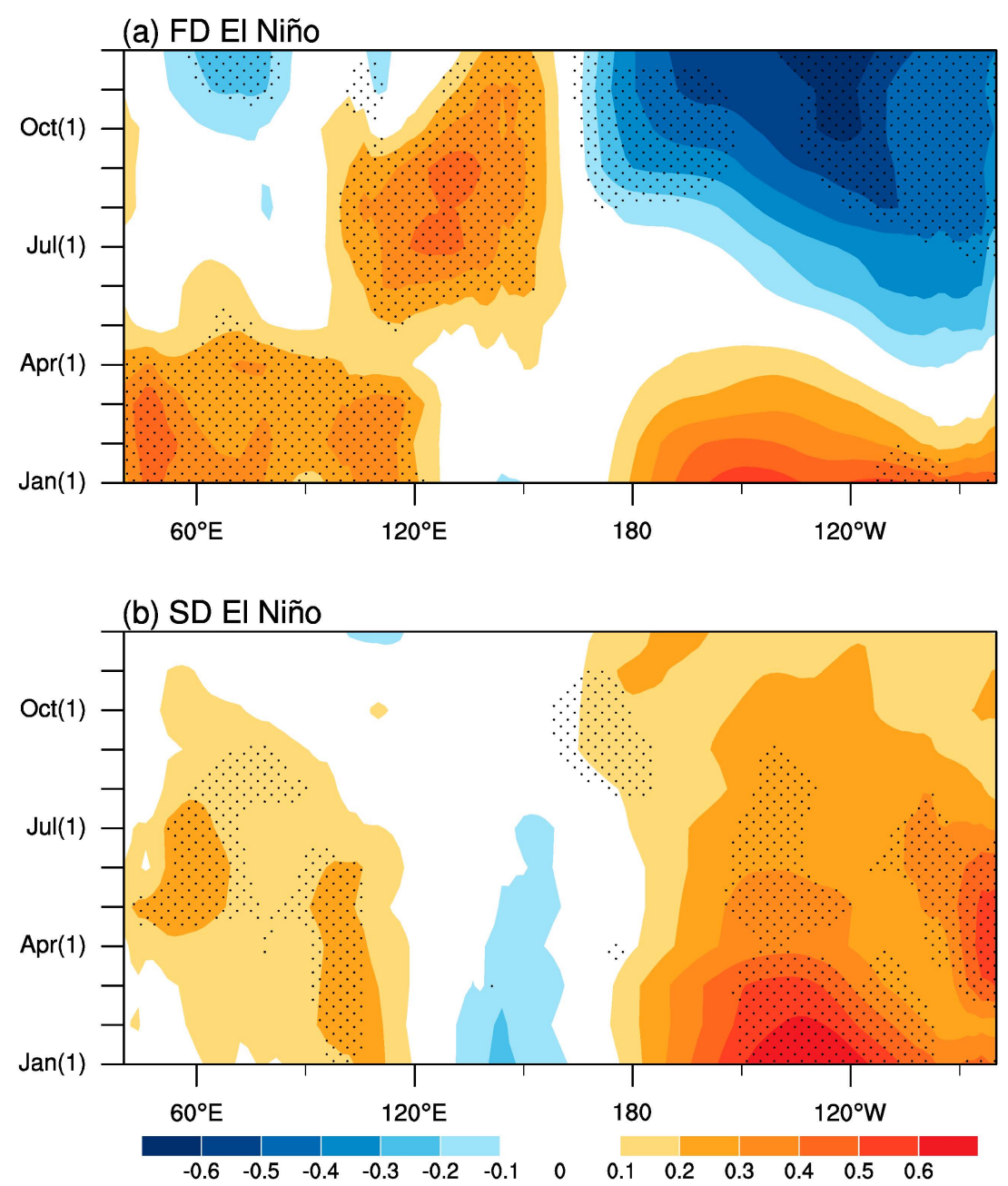

Figure 4. Temporal evolution of SST forcing in (a) FD El Niño years and (b) SD El Niño years averaged over the $20^{\circ} \mathrm{S}-20^{\circ} \mathrm{N}$ region. 
Figure 5 presents anomalous $850 \mathrm{hPa}$ winds and geopotential height in JJA(1) in six sensitivity experiments. In FD_All-Control run (Figure 5a), there were large-scale anticyclone anomalies and positive geopotential height anomalies over the NWP, Northeast Asia, and the mid-latitude North Pacific, which could roughly reproduce the results of composite in the observation (Figure 2a). In SD_All-Control run (Figure 5b), although the NWPAC shift eastward and the cyclone anomalies over the mid-latitude North Pacific and the Northeast Asia were cut off, a significant meridional dipole circulation anomaly pattern dominated over the North Pacific, roughly resembling the observed results in Figure 2b. The realistic responses in FD_All-Control, and SD_All-Control verified that the atmospheric circulation anomalies over the North Pacific were primarily dominated by the tropical SST anomalies, and the ECHAM5 model was able to reproduce the extratropical circulation response to the tropical SST anomalies.

(a) FD_All -Control

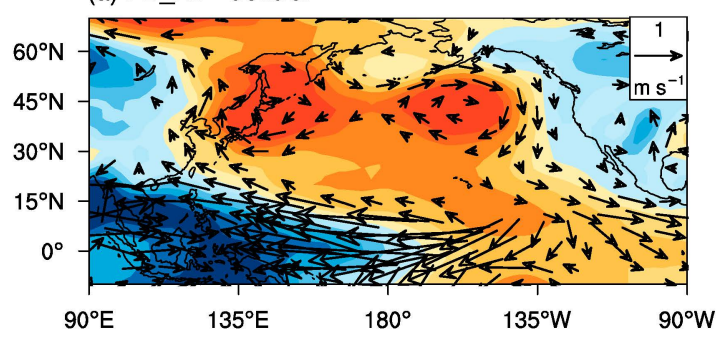

(c) FD_TCEP - Control

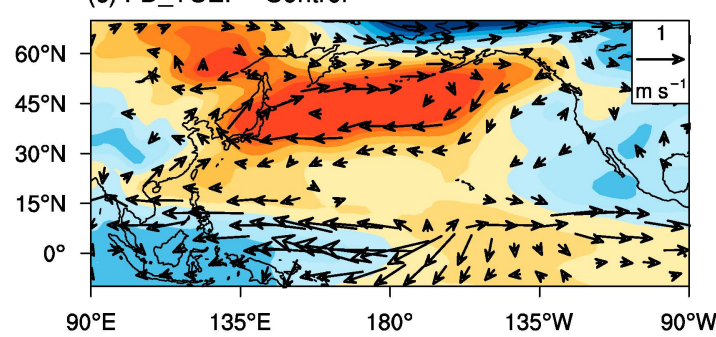

(e) FD_MC-Control

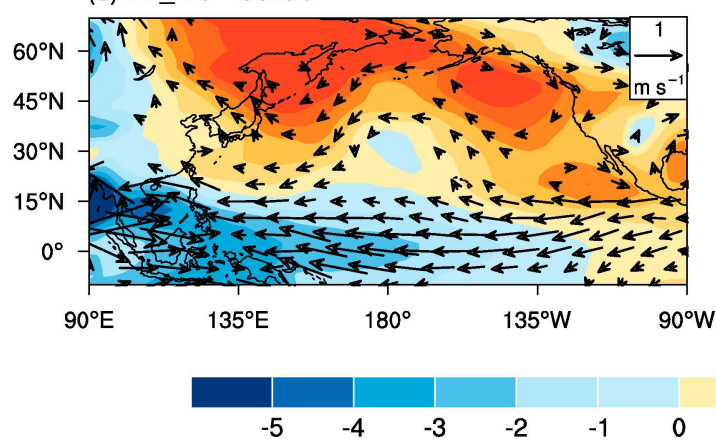

(b) SD_All-Control

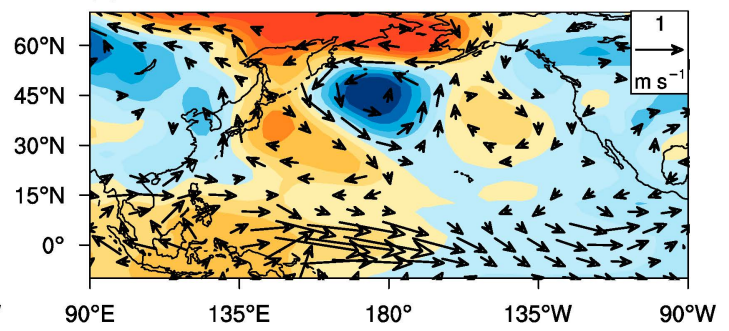

(d) SD_TCEP - Control

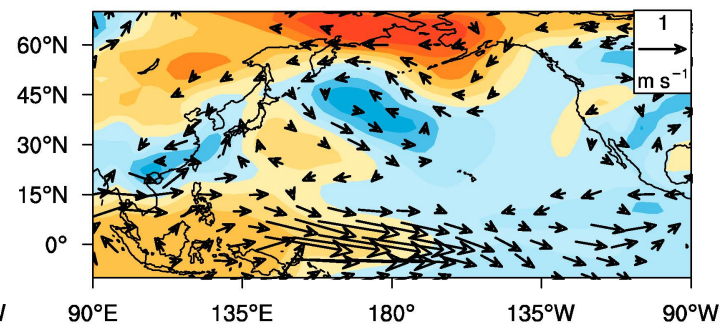

(f) SD_TIO-Control

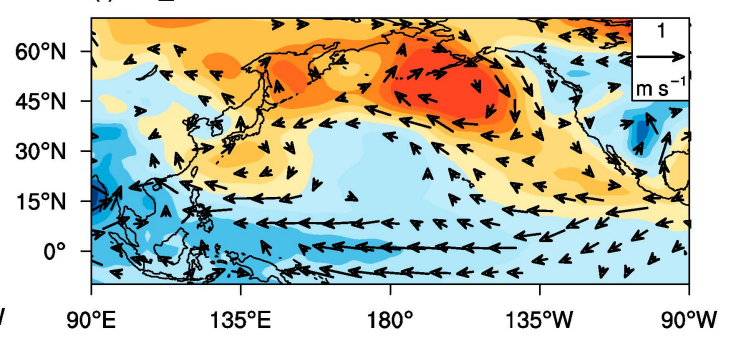

gpm

Figure 5. Difference of $850 \mathrm{hPa}$ winds (vectors) and geopotential height (shading) in JJA(1) between (a) FD_All run, (b) SD_All run, (c) FD_TCEP run, (d) SD_TCEP run, (e) FD_MC run, and (f) SD_TIO run, respectively, and Control run.

Previous studies indicated that the cold TCEP SST anomalies were of benefit to maintaining the NWPAC anomalies [18,32,33] and strengthen the NPH variability [21]. As expected, there were conspicuous anticyclone anomalies and 850-hPa positive geopotential height anomalies over the NWP and the mid-latitude North Pacific in FD_TCEP-Control (Figure 5c), which was consistent with previous studies [18,21,32,33]. Meanwhile, there were also prominent anticyclone anomalies and positive geopotential height anomalies over the NWP and the mid-latitude North Pacific in the FD_MC-Control (Figure 5e), which suggests that the MC SST anomalies contribute to the maintenance of the NWPAC anomalies $[18,19,34,35]$ and also were of benefit to strengthening the NPH. 
In SD_TCEP-Control, the warm SST anomalies in the TCEP trigger a pair of cyclone anomalies at low-level on both side of the equator (Figure 5d), and resultant anticyclonic wind anomalies and cyclonic wind anomalies were generated on their western side (Figure 5d), which indicated that the warm SST anomalies in the TCEP tended to strengthen the eastern part of the NWPAC anomalies and weaken their western part. In addition, there was also a meridional dipole geopotential height pattern over the North Pacific (Figure 5d), resembling that in SD_All-Control (Figure 5b). Note that the warm SST anomalies in the TCEP not only forced an anomalous cyclone over the mid-latitude North Pacific but also enhanced the eastern part of the NWPAC anomalies during SD El Niño summers. In SD_TIO-Control, warm SST anomalies in the TIO force conspicuous anticyclone anomalay over the NWP through triggering a warm Kelvin wave (Figure 5e) [20,36-38], and resultant weak cyclonic wind anomalies and strong anticyclone anomalies were excited on the northeastern side of the NWPAC. In general, TIO warming plays a crucial role in maintaining the NWPAC anomalies and contributes little to the NPH variability during SD El Niño summers.

The results of sensitivity experiments suggest that the circulation anomalies over the mid-latitude North Pacific were primarily affected by the SST anomalies in the TCEP and the MC. Warm SST anomalies in the TCEP corresponded to the anomalous cyclone over the mid-latitude North Pacific, while there was an anomalous anticyclone when the SST anomalies in the TCEP was negative, and warm SST anomalies in the MC favored enhancing the NPH. These relationships are also presented in Figure 6, which shows the variability of NPH was closely associated with the MC SST anomalies and the TCEP SST anomalies.

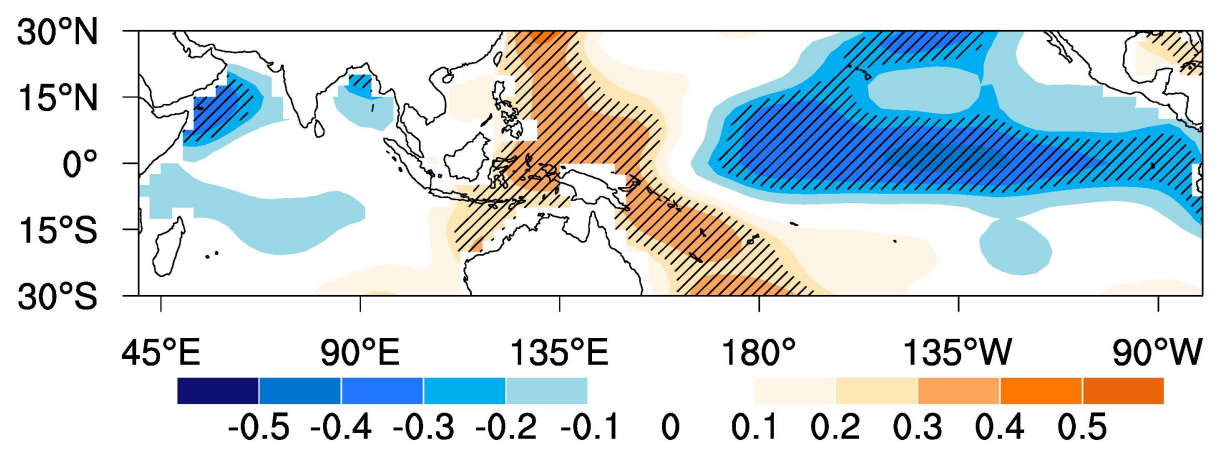

Figure 6. Correlation coefficients between the NPH index and SST anomalies during El Niño decaying summers. The shadow denotes the $95 \%$ confidence level for SST anomalies based on a two-tailed Student's $t$-test.

The mid-latitude atmospheric response over the North Pacific to ENSO forcing has been studied extensively. Bjerknes $[39,40]$ linked warm SST anomalies in the tropical Pacific to a deeper than normal Aleutian low, which is also supported by theoretical and modeling studies of the atmospheric circulation [41-44]. As mentioned in previous studies, atmosphere circulation driven by tropical heating at low level excites associated deep convection and upper-level vorticity anomalies, generating a pattern of stationary Rossby wave trains that propagate to the high latitudes $[45,46]$. The tropical SST anomalies in the TCEP provided the opposite effect on the upper-level atmospheric circulation during FD El Niño summers and SD El Niño summers (Figure 5a,b), triggering different patterns of stationary Rossby wave trains, thereby giving rise to the opposite response of mid-latitude circulation anomalies to tropical SST anomalies.

\section{Impacts on Summer Climate in East Asia}

Boreal summer is the rainy season in East Asia brought about by the EASM. Devasting floods, droughts, and related heat waves occur frequently and have considerable impacts on the livelihood of people in East Asia. The distinct impacts of El Niño decay pace on the circulation anomalies over the North Pacific and East Asia could induce different summer 
climate in East Asia. Figures 7 and 8 show the composite of surface air temperature anomalies, rainfall anomalies, and $850 \mathrm{hPa}$ circulation anomalies in FD El Niño summers and SD El Niño summers, respectively. During FD El Niño summers, the strong southwesterly anomalies of the NWPAC could reach mid- to high-latitudes and bring warm and wet air, leading to warmer than normal in most areas of Northern China (Figure 7a). Similarly, influenced by the strong southwesterly anomalies of the NWPAC, positive rainfall anomalies generate over most areas of Northern China and the Yangzi River basin (Figure 8a). Conversely, rainfall anomalies over Northeast Asia were less than normal due to the domination of an anomalous anticyclone over there. During SD El Niño summers, the anomalous southwesterlies of the NWPAC transport water vapor to the Yangzi River basin, and the anomalous northerlies of the mid-latitude cyclone anomalies bring cold and dry air, which is conducive to form positive rainfall anomalies over the Yangzi River basin and Central China [47] and negative air temperature anomalies in Northeast Asia.

(a) FD EI Niño

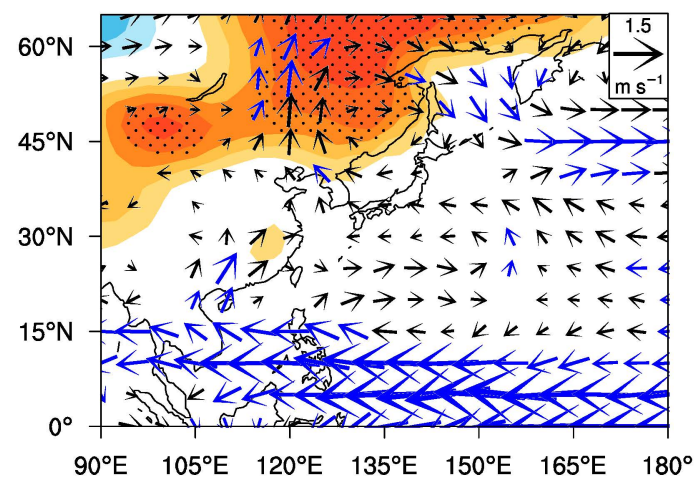

(b) SD EI Niño

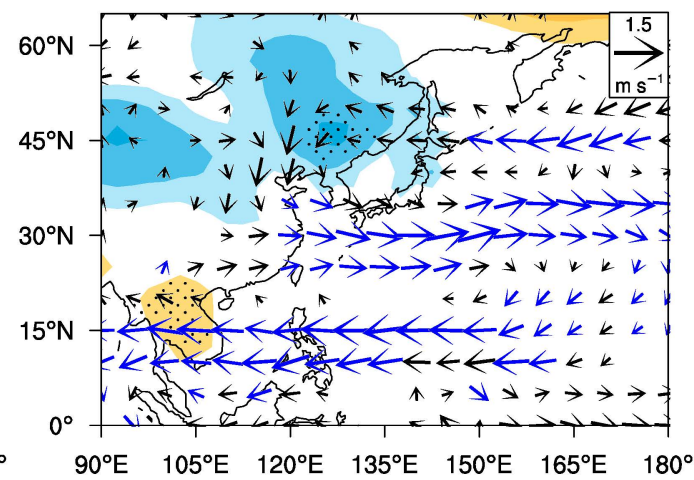

\begin{tabular}{llllll}
\hline-0.5 & -0.4 & -0.3 & -0.2 & -0.1 & 0
\end{tabular}

$\begin{array}{llllll}0.1 & 0.2 & 0.3 & 0.4 & 0.5 & \mathrm{~K}\end{array}$

Figure 7. Same as Figure 2 but for the surface air temperature anomalies (shaded) and $850 \mathrm{hPa}$ wind anomalies (vectors) in (a) FD El Niño summers and (b) SD El Niño summers.

(a) FD El Niño

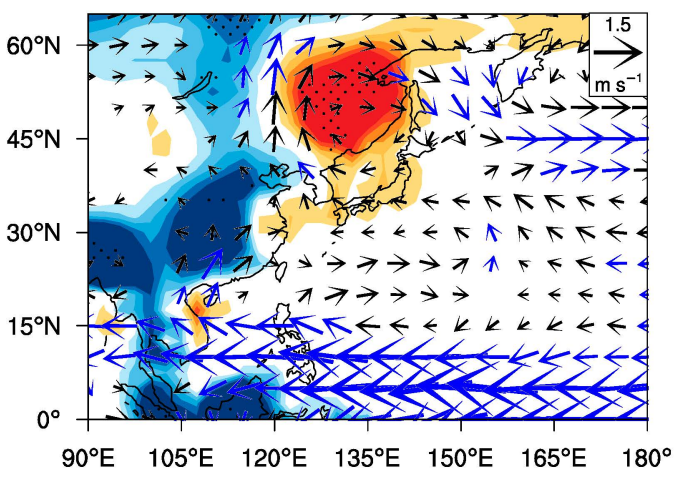

$\begin{array}{llllll}-0.25 & -0.2 & -0.15 & -0.1 & -0.05 & 0\end{array}$ (b) SD EI Niño

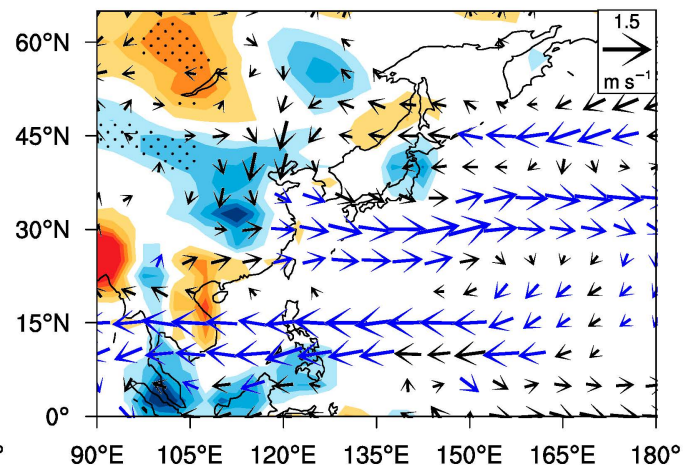

$\begin{array}{lllll}0.05 & 0.1 & 0.15 & 0.2 & 0.25 \\ \mathrm{~mm} \mathrm{day}^{-1}\end{array}$

Figure 8. Same as Figure 2 but for the rainfall anomalies (shaded), $850 \mathrm{hPa}$ wind anomalies (vectors) in (a) FD El Niño summers and (b) SD El Niño summers.

Previous studies suggested that the distinct El Niño decay paces have different impacts on the Indo-Pacific, Korean peninsula, and Eastern China [18,48-50]. In this study, it is noteworthy that the opposite atmospheric circulation anomaly patterns over the midlatitude North Pacific in FD El Niño summers and SD El Niño summers led to opposite air 
temperature anomalies and rainfall anomalies over Northeast Asia, which inspires us that more attention should be paid to the El Niño decay pace in predicting the summer climate in East Asia.

\section{Conclusions}

In this study, we examined the impacts of different El Niño decay pace on the atmospheric circulation anomalies over East Asia and the North Pacific during El Niño decay summers. The difference in El Niño decay pace leads to different SST pattern-the SST anomalies manifest a dipole pattern with warming in the MC and cooling in the TCEP during FD El Niño summers, whereas warm SST anomalies in the TCEP persist to decaying summer and basin-wide positive SST anomalies generate in the TIO during SD El Niño summers. Accordingly, a basin-scale anticyclone anomaly and geopotential height anomalies present over the whole North Pacific during FD El Niño summers. Conversely, the SD El Niño events tend to generate a north-south out-of-phase geopotential height anomaly pattern over the NWP and the mid-latitude North Pacific during its decay summer. Based on the statistical analyses and numerical experiments, we reveal that the El Niño decay pace is a key factor determining the circulation anomalies over East Asia and the North Pacific.

By using the atmospheric general circulation model experiments, we find that the NWPAC anomalies are mainly regulated by TIO SST anomalies through forcing a Kelvin wave response in SD El Niño summers, while they are maintained by the cold TCEP SST anomalies and warm MC SST anomalies in FD El Niño summers. In addition, the SST anomalies in the TCEP is believed to play a dominant role in modulating the circulation anomalies over the mid-latitude North Pacific in FD El Niño summers and SD El Niño summers. The impacts of TCEP SST anomalies on the mid-latitude circulation anomalies are by means of triggering stationary Rossby wave trains at the upper-level, and then the Rossby wave trains propagate to high latitude. Because of the opposite SST anomalies in the TCEP in FD El Niño summers and SD El Niño summers, there are opposite circulation anomalies over the mid-latitude North Pacific.

The different circulation anomalies over East Asia and the North Pacific produce distinct climate effects during different El Niño decaying summers. During FD El Niño summers, influenced by the large-scale anticyclone anomalies and resultant strong southwesterly anomalies, positive rainfall anomalies, and air temperature anomalies generate over most areas of Northern China. Conversely, rainfall anomalies over Northeast Asia are less than normal due to the domination of an anomalous anticyclone over there. During SD El Niño summers, affected by the mid-latitude cyclone anomalies, positive rainfall anomalies present over the Yangzi River basin and Central China, and air temperature anomalies in Northeast Asia are cooler than normal.

Author Contributions: W.J. and G.L. conceptualized the study; W.J. performed statistical analysis and sensitivity experiments; G.L. contributed to improving the analysis and interpretation. W.J. and G.W. wrote the paper and edited and finalized the manuscript. All authors have read and agreed to the published version of the manuscript.

Funding: This work is supported by the Fundamental Research Funds for the Central Universities (B210202139 and B210201015), the National Natural Science Foundation of China (42005022 and 41831175) and the Natural science foundation of Jiangsu Province (BK20200532).

Data Availability Statement: Publicly available datasets were analyzed in this study. The National Centers for Environment Prediction-National Center for Atmospheric Research (NCEP/NCAR) reanalysis-1 datasets are provided by the National Oceanic and Atmospheric Administration (NOAA), which are available online from https: / www.esrl.noaa.gov/psd/data / gridded/data.ncep.reanalysis $\mathrm{html}$, and the observational air temperature and precipitation data are provided by the Climatic Research Unit at the University of East Anglia (https://1r1.uea.ac.uk/cru/data). ERSST.v5 data is provided by the NOAA/OAR/ESRL PSL, Boulder, Colorado, USA, from https:/ / psl.noaa.gov/. 
Acknowledgments: The authors thank the two anonymous reviewers for their constructive comments that lead to improvements in the manuscript.

Conflicts of Interest: The authors declare no conflict of interest.

\section{References}

1. Hu, K.; Huang, G.; Wu, R. A Strengthened Influence of ENSO on August High Temperature Extremes over the Southern Yangtze River Valley since the Late 1980s. J. Clim. 2013, 26, 2205-2221. [CrossRef]

2. Huang, R.; Chen, J.; Huang, G. Characteristic's and variations of the East Asian monsoon system and its impacts on climate disasters in China. Adv. Atmos. Sci. 2007, 24, 993-1023. [CrossRef]

3. Jiang, T.; Kundzewicz, Z.W.; Su, B. Changes in monthly precipitation and flood hazard in the Yangtze River Basin, China. Int. J. Climatol. 2008, 28, 1471-1481. [CrossRef]

4. Chang, C.P.; Zhang, Y.S.; Li, T. Interannual and interdecadal variations of the East Asian summer monsoon and tropical Pacific SSTs. Part I: Roles of the subtropical ridge. J. Clim. 2000, 13, 4310-4325. [CrossRef]

5. Fu, C.; Ye, D. The tropical very low-frequency oscillation on interannual scale. Adv. Atmos. Sci. 1988, 5, 369-388.

6. Huang, R.; Wu, Y. The influence of ENSO on the summer climate change in china and its mechanism. Adv. Atmos. Sci. 1989, 6, 21-32. [CrossRef]

7. Chou, C.; Huang, L.F.; Tu, J.Y.; Tseng, L.S.; Hsueh, Y.C. El Niño Impacts on Precipitation in the Western North Pacific-East Asian Sector. J. Clim. 2009, 22, 2039-2057. [CrossRef]

8. Wang, B.; Wu, R.G.; Fu, X.H. Pacific-East Asian teleconnection: How does ENSO affect East Asian climate? J. Clim. 2000, 13, 1517-1536. [CrossRef]

9. Zhang, W.; Jin, F.-F.; Stuecker, M.F.; Wittenberg, A.T.; Timmermann, A.; Ren, H.-L.; Kug, J.-S.; Cai, W.; Cane, M. Unraveling El Niño's impact on the East Asian Monsoon and Yangtze River summer flooding. Geophys. Res. Lett. 2016, 43, 11375-11382. [CrossRef]

10. Lau, N.C.; Nath, M.J. ENSO modulation of the interannual and intraseasonal variability of the East Asian monsoon-A model study. J. Clim. 2006, 19, 4508-4530. [CrossRef]

11. Wu, R.G.; Hu, Z.Z.; Kirtman, B.P. Evolution of ENSO-related rainfall anomalies in East Asia. J. Clim. 2003, 16, 3742-3758. [CrossRef]

12. Zhang, R.H.; Sumi, A.; Kimoto, M. Impact of El Niño on the East Asian monsoon: A diagnostic study of the ' $86 / 87$ and ' $91 / 92$ events. J. Meteor. Soc. Jpn. 1996, 74, 49-62. [CrossRef]

13. Zhang, R.H.; Sumi, A.; Kimoto, M. A diagnostic study of the impact of El Niño on the precipitation in China. Adv. Atmos. Sci. 1999, 16, 229-241. [CrossRef]

14. Barnett, T.P. The interaction of multiple time scales in the tropical climate system. J. Clim. 1991, 4, 269-285. [CrossRef]

15. Kim, K.Y.; Kim, Y.Y. Mechanism of Kelvin and Rossby waves during ENSO events. Meteor. Atmos. Phys. 2002, 81, 169-189. [CrossRef]

16. Chen, W.; Park, J.-K.; Dong, B.; Lu, R.; Jung, W.-S. The relationship between El Niño and the western North Pacific summer climate in a coupled GCM: Role of the transition of El Niño decaying phases. J. Geophys. Res.-Atmos. 2012, 117. [CrossRef]

17. Feng, J.; Wang, L.; Chen, W. How Does the East Asian Summer Monsoon Behave in the Decaying Phase of El Niño during Different PDO Phases? J. Clim. 2014, 27, 2682-2698. [CrossRef]

18. Jiang, W.; Huang, G.; Huang, P.; Wu, R.; Hu, K.; Chen, W. Northwest Pacific anticyclonic anomalies during post-El Niño summers determined by the pace of El Niño decay. J. Clim. 2019, 32, 3487-3503. [CrossRef]

19. Sui, C.H.; Chung, P.H.; Li, T. Interannual and interdecadal variability of the summertime western North Pacific subtropical high Geophys. Res. Lett. 2007, 34, 6. [CrossRef]

20. Xie, S.-P.; Hu, K.; Hafner, J.; Tokinaga, H.; Du, Y.; Huang, G.; Sampe, T. Indian Ocean Capacitor Effect on Indo-Western Pacific Climate during the Summer following El Niño. J. Clim. 2009, 22, 730-747. [CrossRef]

21. Yun, K.S.; Yeh, S.W.; Ha, K.J. Distinct impact of tropical SSTs on summer North Pacific high and western North Pacific subtropical high. J. Geophys. Res. Atmos. 2013, 118, 4107-4116. [CrossRef]

22. Yun, K.S.; Yeh, S.W.; Ha, K.J. Covariability of western tropical Pacific-North Pacific atmospheric circulation during summer. Sci. Rep. 2015, 5, 16980. [CrossRef] [PubMed]

23. Lau, N.C.; Leetmaa, A.; Nath, M.J.; Wang, H.L. Influences of ENSO-induced Indo-Western Pacific SST anomalies on extratropical atmospheric variability during the boreal summer. J. Clim. 2005, 18, 2922-2942. [CrossRef]

24. Paek, H.; Yu, J.-Y.; Zheng, F.; Lu, M.-M. Impacts of ENSO diversity on the western Pacific and North Pacific subtropical highs during boreal summer. Clim. Dyn. 2016, 52, 7153-7172. [CrossRef]

25. Kalnay, E.; Kanamitsu, M.; Kistler, R.; Collins, W.; Deaven, D.; Gandin, L.; Iredell, M.; Saha, S.; White, G.; Woollen, J.; et al. The NCEP/NCAR 40-year reanalysis project. Bull. Amer. Meteor. Soc. 1996, 77, 437-471. [CrossRef]

26. Huang, B.; Thorne, W.P.; Banzon, V.F.; Boyer, T.; Chepurin, G.; Lawrimore, J.H.; Menne, M.J.; Smith, T.M.; Vose, R.S.; Zhang, H.M.; et al. NOAA Extended Reconstructed Sea Surface Temperature Version 5 (ERSSTv5), Upgrades, validations, and intercomparisons. J. Climate 2017, 30, 8179-8205. [CrossRef]

27. Roeckner, E.; Bäuml, G.; Bonaventura, L.; Brokopf, R.; Esch, M.; Giorgetta, M.; Hagemann, S.; Kirchner, I.; Kornblueh, L.; Manzini, E.; et al. The atmospheric general circulation model ECHAM 5. Part I: Model description. Tech. Rep. 2003, $349,127$. 
28. Tiedtke, M. A comprehensive mass flux scheme for cumulus parameterization in large-scale models. Mon. Weather Rev. 1989, 117, 1779-1800. [CrossRef]

29. Nordeng, T.E. Extended versions of the convective parameterization scheme at ECMWF and their impact on the mean and transient activity of the model in the tropics. Tech. Memo. 1994, 206, 41.

30. Yu, J.-Y.; Lu, M.-M.; Kim, S.T. A change in the relationship between tropical central Pacific SST variability and the extratropical atmosphere around 1990. Environ. Res. Lett. 2012, 7, 034025. [CrossRef]

31. Yu, J.-Y.; Paek, H.; Saltzman, E.S.; Lee, T. The Early 1990s Change in ENSO-PSA-SAM Relationships and Its Impact on Southern Hemisphere Climate. J. Clim. 2015, 28, 9393-9408. [CrossRef]

32. Fan, L.; Shin, S.I.; Liu, Q.Y.; Liu, Z.Y. Relative importance of tropical SST anomalies in forcing East Asian summer monsoon circulation. Geophys. Res. Lett. 2013, 40, 2471-2477. [CrossRef]

33. Chen, M.Y.; Yu, J.Y.; Wang, X.; Jiang, W. The changing impact mechanisms of a diverse El Niño on the Western Pacific Subtropical High. Geophys. Res. Lett. 2019, 46, 953-962. [CrossRef]

34. Chung, P.-H.; Sui, C.-H.; Li, T. Interannual relationships between the tropical sea surface temperature and summertime subtropical anticyclone over the western North Pacific. J. Geophys. Res. Atmos. 2011, 116, D13111. [CrossRef]

35. Lu, R.; Li, Y.; Dong, B. External and internal summer atmospheric variability in the western North Pacific and East Asia. J. Meteor. Soc. Jpn. 2006, 84, 447-462. [CrossRef]

36. Yang, J.; Liu, Q.; Xie, S.-P.; Liu, Z.; Wu, L. Impact of the Indian Ocean SST basin mode on the Asian summer monsoon. Geophys. Res. Lett. 2007, 34, L02708. [CrossRef]

37. Yang, J.L.; Liu, Q.Y.; Liu, Z.Y. Linking Observations of the Asian Monsoon to the Indian Ocean SST: Possible Roles of Indian Ocean Basin Mode and Dipole Mode. J. Clim. 2010, 23, 5889-5902. [CrossRef]

38. Wu, B.; Zhou, T.J.; Li, T. Seasonally evolving dominant interannual variability modes of East Asian climate. J. Clim. 2009, 22, 2992-3005. [CrossRef]

39. Bjerknes, J. A possible response of atmospheric Hadley circulation to equatorial anomalies of ocean temperature. Tellus 1966, 18, 820-829. [CrossRef]

40. Bjerknes, J. Atmospheric teleconnections from equatorial Pacific. Mon. Weather Rev. 1969, 97, 163. [CrossRef]

41. Blackmon, M.L.; Geisler, J.E.; Pitcher, E.J. A general-circulation model study of January climate anomaly patterns associated with interannual variation of equatorial Pacific sea-surface temperatures. J. Atmos. Sci. 1983, 40, 1410-1425. [CrossRef]

42. Horel, J.D.; Wallace, J.M. Planetary-scale atmospheric phenomenon associated with the southern oscillation. Mon. Weather Rev. 1981, 109, 813-829. [CrossRef]

43. Hoskins, B.J.; Karoly, D.J. The steady linear response of a spherical atmosphere to thermal and orographic forcing. J. Atmos. Sci. 1981, 38, 1179-1196. [CrossRef]

44. Webster, P.J. Mechanisms determining the atmospheric response to sea-surface temperature anomalies. J. Atmos. Sci. 1981, 38, 554-571. [CrossRef]

45. Sardeshmukh, P.D.; Hoskins, B.J. The generation of global rotational flow by steady idealized tropical convergence. J. Atmos. Sci. 1988, 45, 1228-1251. [CrossRef]

46. Umakanth, U.; Vellore, R.K.; Krishnan, R.; Choudhury, A.D.; Bisht, J.S.; Di Capua, G.; Coumou, D.; Donner, R.V. Meridionally Extending Anomalous Wave Train over Asia During Breaks in the Indian Summer Monsoon. Earth Syst. Environ. 2019, 3, 353-366. [CrossRef]

47. Li, X.; Lu, R. Extratropical factors affecting the variability in summer precipitation over the Yangtze River basin. J. Clim. 2017, 30, 8357-8374. [CrossRef]

48. Chen, Z.; Du, Y.; Wen, Z.; Wu, R.; Wang, C.J.C.D. Indo-Pacific climate during the decaying phase of the 2015/16 El Niño: Role of southeast tropical Indian Ocean warming. Clim. Dyn. 2018, 50, 4707-4719. [CrossRef]

49. Chowdary, J.S.; Harsha, H.S.; Gnanaseelan, C.; Srinivas, G.; Parekh, A.; Pillai, P.; Naidu, C.V. Indian summer monsoon rainfall variability in response to differences in the decay phase of El Niño. Clim. Dyn. 2017, 48, 2707-2727. [CrossRef]

50. Yeo, S.-R.; Yeh, S.-W.; Kim, Y.; Yim, S.-Y. Monthly climate variation over Korea in relation to the two types of ENSO evolution. Int. J. Climatol. 2018, 38, 811-824. [CrossRef] 